\title{
Long-Term Kinetics of Serum and Xanthoma Cholesterol Radioactivity in Patients with Hypercholesterolemia
}

\author{
Paul Samuel, William Perl, Charles M. Holtzman, \\ Norman D. Rochman, and Sidney Lieberman \\ From the Departments of Medicine, The Long Island Jewish Medical Center, \\ New Hyde Park, New York 11040, The Long Island Jewish Medical Center- \\ Queens Hospital Center Affiliation, Jamaica, New York 11432, The College \\ of Medicine and Dentistry of New Jersey at Newark, Newark, New Jersey \\ 07103, and the Departments of Chemistry and Mathematics, Queens College \\ of The City University of New York, Flushing, New York 11367
}

A B S T R A C T In four patients with hypercholesterolemia (type II hyperlipoproteinemia) and xanthomatosis the decay of serum cholesterol specific activity was followed for 53-63 wk after pulse labeling. Specific activity of biopsied xanthoma cholesterol was measured four times in the course of the study. The xanthoma specific activity curve crossed and thereafter remained above the serum specific activity curve. The average ratio of xanthoma to serum specific activity was 4.7 at the end of the study. The final half-time of the xanthoma decay curves was significantly greater (average: 200 days) than the slowest half-time of serum specific activity decay (average: 93 days). The data were analyzed by input-output analysis and yielded the following results. The average value for the total input rate of body cholesterol ( $\mathrm{I}_{\mathrm{T}}$ ) (sum of dietary and biosynthesized cholesterol) was $1.29 \mathrm{~g} /$ day. The average size of the rapidly miscible pool of cholesterol $\left(\mathrm{M}_{\mathrm{a}}\right)$ was $55.7 \mathrm{~g}$, and of the total exchangeable body mass of cholesterol (M) $116.5 \mathrm{~g}$. The average value of $\mathrm{M}-\mathrm{M}_{\mathrm{a}}$ (remaining exchangeable mass of cholesterol) was $60.8 \mathrm{~g}$. The derived values for exchangeable masses of cholesterol, in the present patients with marked hypercholesterolemia, were significantly larger than in a group of patients with normal serum lipids in previous studies. One of the four patients died of a sudden acute myocardial infarction 53 wk after pulse labeling. Specific activity of aortic wall and atheroma cholesterol was 3.12 times that of serum. The ratio was close to 2 for adipose tissue and spleen, and was slightly above 1 or was close to unity in most other organs studied, with the exception of brain which showed a ratio of 0.19 .

Received for publication 22 April 1971 and in recised form 23 August 1971.

\section{INTRODUCTION}

In recent years tracer methods have become available to estimate the size and turnover of body masses of cholesterol in man. After pulse labeling by the intravenous injection of a tracer dose of radioactive cholesterol, the decay curves of specific activity were analyzed using a two-compartmental model (1-4) or by input output analysis $(5,6)$. Recently Wilson reported that in the baboon a single organ may contain cholesterol turning over at different rates (thus belonging to different pools), and that part of the cholesterol content of many body tissues remained unlabeled in this species 10-13 wk after the injection of the tracer (7).

In the present study the problem of the relationship of serum and tissue cholesterol turnover kinetics was investigated in man. The long-term decay of serum cholesterol specific activity was studied in four patients with hypercholesterolemia, who also had tendinous and/ or tuberous xanthomas, a presumably very slowly turning over mass of cholesterol. The specific activity of xanthoma-cholesterol was studied by periodic biopsies. One of the four patients died suddenly of an acute myocardial infarction $53 \mathrm{wk}$ after pulse labeling, and measurements of organ cholesterol specific activity became available.

\section{METHODS}

Four patients were studied. The age, sex, and clinical diagnoses are included in Table I. Each patient had hypercholesterolemia, with normal triglyceride levels (type II hyperlipoproteinemia). Diffuse xanthoma tendinosum and/or tuberosum were present in each. All patients were ambulatory and their respective diseases were under good control. Medications, if any, were kept constant and substances 
known to influence serum lipid levels were not given. The diet was uncontrolled, but the patients were instructed to adhere to a low-fat, low-cholesterol diet, which contained approximately $250 \mathrm{mg}$ of cholesterol daily. Carbohydrate comprised $54 \%$ of the total calories, protein $20 \%$, and fat $26 \%$. The patients were given this diet 1 yr or more before the beginning of the present experiments. The weight of the patients is included in Table I. Three were well within the normal limits; one was overweight by an estimated 7 $\mathrm{kg}$. The patients were seen weekly, with the exception of a few appointments that were missed (vacations, family or job engagements, or other reasons). One of the patients (A. W.) was seen weekly for the first $25 \mathrm{wk}$ of the experiment and once every 2 wk thereafter. Physical examinations, complete blood counts, urinalysis, blood urea nitrogen, blood sugar, serum bilirubin, serum glutamic oxalacetic transaminase, lactic dehydrogenase, and cephalin flocculation were carried out periodically. The experiment was explained to each patient (and/or to the parents) in detail and informed consent was obtained. Cholesterol-4- ${ }^{14} \mathrm{C}$ (50 $\mathrm{mCi} / \mathrm{mmole}$ ) (New England Nuclear Corp., Boston, Mass.) was processed as described previously (6). The tracer was incubated with the serum of each individual (6), and 80-82 $\mu \mathrm{Ci}$ of cholesterol-4- ${ }^{14} \mathrm{C}$ was given intravenously to each patient at the beginning of the experiment. There was no evidence of side effects due to the injection of the tracer. After pulse labeling, blood was drawn at each visit weekly or biweekly. Three patients were followed for $63 \mathrm{wk}$ and the remaining subject (A. K.) for 53 wk after the injection of tracer.

Total serum cholesterol concentrations were determined in each sample by the method of Abell, Levy, Brodie, and Kendall (8). Serum triglyceride levels were done by the method of Van Handel and Zilversmit (9). The values given in Table I represent the average and standard deviations of all samples obtained during the study. Serum lipoprotein electrophoresis was carried out by the method of Fredrickson and Lees (10). A separate $3 \mathrm{ml}$ aliquot of the serum was processed as described previously (6) for the determination of serum cholesterol radioactivity. After correction for quenching by the internal standard method, serum cholesterol radioactivity was calculated in disintegrations per minute $(\mathrm{dpm})$. Each sample was counted for 100 min. The counts on the last sample and the coefficient of variation (11) of the observed sample counting rates $\left(V_{B}\right)$ are included in Table II. The value of $V_{s}$ varied from $0.4 \%$ to $0.73 \%$ in the four patients. The results were expressed as 100 times specific activity (dpm per gram total serum cholesterol), divided by the injected dose (dpm) of radioactive cholesterol (per cent of dose of radioactivity given per $1 \mathrm{~g}$ of total serum cholesterol).

Input-output analysis. The theoretical analysis and method of calculation of the serum kinetic data are described elsewhere (5). In brief, if $w(t)$ denotes $100 \times$ specific activity per unit dose $(100 / g$ ) at times $t$ (days), then the total input rate $I_{T}$ ( $g /$ day) of body cholesterol is obtained as the reciprocal of the area integral of $w(t)$, or

$$
\begin{aligned}
I_{T} & =1 / \int_{0}^{\infty} w(t) d t \\
& =69.3 / \Sigma_{j} a_{j}\left(t_{1}\right)_{j} .
\end{aligned}
$$

The mean transit time $\bar{t}_{p}$ (days) of tracer cholesterol is obtained as the ratio of first time moment integral to the area integral of $w(t)$, or

$$
\begin{aligned}
\bar{t}_{p} & =\int_{0}^{\infty} t w(t) d t / \int_{0}^{\infty} w(t) d t \\
& =\Sigma_{j} a_{j}\left(t_{\xi}\right)_{j}{ }^{2} / 0.693 \Sigma_{j} a_{j}\left(t_{j}\right)_{j} .
\end{aligned}
$$

The total exchangeable mass $M(g)$ of body cholesterol is obtained as

$$
\mathbf{M}=\mathbf{I}_{\mathbf{T}} \overline{\mathbf{t}}_{\mathbf{p}} .
$$

The rapidly miscible pool $\mathrm{M}_{\mathrm{a}}(\mathrm{g})$ of body cholesterol is obtained as

$$
\begin{aligned}
M_{\mathbf{a}} & =100 / w(0) \\
& =100 / \Sigma_{j} a_{j}
\end{aligned}
$$

The remaining exchangeable mass of body cholesterol is defined as the difference $M-M_{\mathrm{a}}(\mathrm{g})$. Equations 2, 4, and 7 result from equations 1,3 , and 6 respectively if the experimental data are fitted by a sum of exponentials.

$$
w(t)=\Sigma_{j} a_{j} \exp \left[0.693 t /\left(t_{j}\right)_{j}\right]
$$

Equations 1, 3, and 6 emphasize that curve-fitting the data by a sum of exponentials is not necessary in order to obtain $\mathrm{I}_{\mathrm{T}}, \mathrm{M}$, and $\mathrm{M}_{\mathrm{a}}$. The present data were analyzed both by equations 1, 3, 6 (point-by-point method) and by equations 2, 4, and 7 (sum-of-exponentials method). In the point-bypoint method the data were plotted semilogarithmically, extrapolated back to $t=0$ by a smooth curve drawn through the first few data points, and extrapolated forward from the maximum measurement time to infinite time by the last straight line indicated by the data (exponential extrapolation). The integrals in equations 1 and 3 were evaluated by the trapezoidal rule from time zero to the maximum measurement time and by analytic formula from the maximum measurement time to infinite time. In the sum-of-exponential method the last straight line indicated by the semilogarithmically plotted data was taken as the slowest exponential of a sum-of-exponentials curve fit of the entire set of data points. The remaining exponentials were obtained by the well known graphical curve-peeling process. This process yielded the parameters in equation (8). Two exponentials (patient T. B.) or three exponentials (the remaining patients) represented the data satisfactorily. Equations 2, 4, and 7 were then applied. The values obtained by the sumof-exponentials method differed only insignificantly (average $2 \%$, maximum $3.4 \%$ ) from the values obtained by the point-by-point method. Therefore only the results obtained by the sum-of-exponentials method will be presented.

Xanthoma analyses. Biopsies of xanthomas were carried out four times during the experiment: at $9 \mathrm{wk}, 26 \mathrm{wk}$, and $47 \mathrm{wk}$ (45 wk in one subject) after pulse labeling; the last biopsy was done at the end of the follow-up period ( 63 wk) in three patients. In the remaining subject (A. K.) the last sample of xanthoma material was obtained at autopsy $53 \mathrm{wk}$ after the injection of tracer. Biopsies were taken by one of us (N. D. R.), a surgeon, of randomly chosen xanthomas under local anesthesia through a small incision of the skin. Of the total of 15 xanthoma biopsies in the four patients, eight were taken from the left hand, one from the right hand, four from the left elbow, and two from the right elbow. The incisions were sutured and healed without complications in each case. The material obtained weighed from 35 to $350 \mathrm{mg}$; the average for the 
TABLE I

Experimental Data of

\begin{tabular}{|c|c|c|c|c|}
\hline Patient & Age & Sex & Diagnosis & Weight \\
\hline & $y r$ & & & $\mathrm{~kg}$ \\
\hline A. $\mathrm{K}$. & 18 & $\mathbf{M}$ & $\begin{array}{l}\text { Coronary artery disease. Tendonous } \\
\text { and tuberous xanthomatosis. }\end{array}$ & 54.4 \\
\hline N. A. & 50 & $\mathrm{~F}$ & $\begin{array}{l}\text { Coronary artery disease. Tendonous } \\
\text { xanthomatosis. }\end{array}$ & 54.4 \\
\hline T. B. & 45 & $\mathrm{M}$ & $\begin{array}{l}\text { Coronary artery disease. Tendonous } \\
\text { xanthomatosis. }\end{array}$ & 91.9* \\
\hline A. W. & 46 & $\mathbf{M}$ & $\begin{array}{l}\text { Coronary artery disease. Tendonous } \\
\text { and tuberous xanthomatosis. }\end{array}$ & 74.7 \\
\hline
\end{tabular}

Average

$I_{\mathrm{T}}=$ total input rate of dietary plus biosynthesized cholesterol; $\mathrm{M}_{\mathrm{a}}=$ rapidly miscible pool of cholesterol; $M=$ total exchangeable mass of cholesterol; $M-M_{a}=$ remaining exchangeable mass of cholesterol; $\bar{t}_{p}=$ mean transit time.

* Overweight by an estimated $7 \mathrm{~kg}$.

group was $122 \mathrm{mg}$ per biopsy. Xanthoma biopsies were carefully freed of any visible extraneous tissues, such as adipose tissue and blood, and were homogenized. To each homogenate $100 \mathrm{ml}$ of ethanol and $30 \mathrm{ml}$ of $33 \%$ potassium hydroxide $(\mathrm{KOH})$ were added, and the mixture was refluxed for $6 \mathrm{hr}$. After saponification, the solution was concentrated and the sample was made up to contain $50 \mathrm{ml}$ of water: ethanol $(1: 1)$. Neutral steroids were extracted four times with $100 \mathrm{ml}$ of hexane. There was no demonstrable radioactivity left in the water-ethanol layer. The hexane extracts were pooled, washed, and concentrated in a steam bath with a gentle nitrogen flow, and brought to $100 \mathrm{ml}$. A measured aliquot of the hexane solution was evaporated to dryness in a liquid scintillation counter vial, and the residue was dissolved in $4 \mathrm{ml}$ of toluene by heating to $50^{\circ} \mathrm{C}$ and gentle stirring. After cooling, $10 \mathrm{ml}$ of scintillation solution was added and radioactivity. was measured in a liquid scintillation spectrometer. Quenching was determined by the addition of known internal standards in $0.1 \mathrm{ml}$ of toluene. Neutral steroid mass was determined on a separate aliquot of the hexane solution in duplicates by the principle of the method of Abell et al. (8).

In order to determine that the extracted neutral steroids consisted principally of cholesterol, the material obtained was subjected to dibromination (12) in two experiments. In the first experiment, the specific activity of the extract was $215 \mathrm{dpm} / \mathrm{mg}$ before, and $219 \mathrm{dpm} / \mathrm{mg}$ after cholesterol was regenerated from the dibromide. In the second experiment the data showed $155 \mathrm{dpm} / \mathrm{mg}$ before, and $157 \mathrm{dpm} / \mathrm{mg}$ after the dibromide procedure. Aliquots of the xanthoma extracts from each patient were analyzed by thin-layer chromatography (benzene: ethyl acetate, 8:2). No spots other than cholesterol were observed. An average of $90.2 \%$ of radioactivity was present in the spots corresponding to cholesterol, the remainder was at the origin or was spread across the plates. Each xanthoma extract was subjected to gas-liquid chromatography $\left(3 \% Q f_{1}\right.$, on Gas Chrom $\left.Q\right)$ and no peaks other than cholesterol were observed.
In order to determine whether xanthoma tissue of different anatomic sites was equally labeled, multiple biopsies were taken in one patient (A. K.) 45 wk after pulse labeling. Three separate specimens were obtained at the same time from the second, third, and fourth fingers of the left hand. The samples were processed separately and the specific activities were $201 \mathrm{dpm} / \mathrm{mg}, 212 \mathrm{dpm} / \mathrm{mg}$, and 232 $\mathrm{dpm} / \mathrm{mg}$ cholesterol respectively. The three figures were averaged $(215 \mathrm{dpm} / \mathrm{mg})$ and the mean figure was used for tabulation and calculations (Table IV and Fig. 1). The data show that the range of specific activity of these three biopsies was $\pm 6.5 \%$, suggesting nearly uniform labeling. A second series of comparisons was made on the autopsy material of patient A. K. Xanthoma tissue was obtained from the left elbow (tuberous and tendinous), right knee (tuberous), and left Achilles tendon (tendinous) and was processed separately. The specific activities were $155 \mathrm{dpm} /$ $\mathrm{mg}, 150 \mathrm{dpm} / \mathrm{mg}$, and $161 \mathrm{dpm} / \mathrm{mg}$ cholesterol respectively of the three samples. Again, the average of these three figures $(155 \mathrm{dpm} / \mathrm{mg}$ ) was used for tabulation (Table IV, Fig. 1). The range was $\pm 3.4 \%$ showing nearly uniform labeling. The data also suggested that there was no significant difference in the labeling of tendinous and tuberous xanthomas.

Tissue analyses. One of the four patients studied was an $18 \mathrm{yr}$ old boy followed by our group since the age of $8 \mathrm{yr}$. His serum cholesterol levels varied between 600 and $900 \mathrm{mg} /$ $100 \mathrm{ml}$ (with normal triglycerides) during the past $10 \mathrm{yr}$, and he had marked diffuse xanthomatosis. He was probably homozygous to the abnormal gene. The pedigree of this family was the subject of a previous publication from this laboratory (13). He developed coronary artery insuffiency, anginal pain, and electrocardiographic changes at exertion at the age of $12 \mathrm{yr}$. He was resistant to most serum cholesterol-reducing regimens (14). He was maintained on nitroglycerin and was clinically stable. In the course of the present study, 53 wk after the administration of the tracer, he developed sudden severe crushing chest pain and was 


\begin{tabular}{|c|c|c|c|c|c|c|c|}
\hline $\begin{array}{l}\text { Average } \\
\text { total } \\
\text { serum } \\
\text { cholesterol } \\
( \pm \mathrm{BD})\end{array}$ & $\begin{array}{l}\text { Average } \\
\text { serum } \\
\text { triglycerides } \\
( \pm \mathrm{sD})\end{array}$ & Type & IT & $\mathbf{M}_{\mathbf{a}}$ & $\mathbf{M}$ & $\mathbf{M}-\mathbf{M}_{\mathbf{a}}$ & $\overline{\mathbf{t}}_{\mathrm{p}}$ \\
\hline $\mathrm{mg} / 100 \mathrm{ml}$ & $\mathrm{mg} / 100 \mathrm{ml}$ & & $g / d a y$ & $g$ & $g$ & $g$ & days \\
\hline $699 \pm 45$ & $78 \pm 15$ & II & 1.25 & 55.2 & 96.9 & 41.7 & 77.5 \\
\hline $542 \pm 26$ & $121 \pm 28$ & II & 1.14 & 36.0 & 98.0 & 62.0 & 86.0 \\
\hline $580 \pm 33$ & $128 \pm 16$ & II & 1.28 & 75.1 & 148 & 72.9 & 116 \\
\hline \multirow[t]{2}{*}{$631 \pm 14$} & $148 \pm 14$ & II & 1.48 & 56.6 & 123 & 66.4 & 82.9 \\
\hline & & & 1.29 & 55.7 & 116.5 & 60.8 & 90.6 \\
\hline
\end{tabular}

dead on arrival at the hospital. On autopsy the right coronary artery was completely occluded and there was severe atherosclerosis present of the anterior descending and circumflex branches of the left coronary artery. Marked cholesterol deposits were noted throughout the body. Samples of tissues were obtained from xanthomas and different organs (Table V) and were carefully cleaned of blood, body fluids, or other tissues. The samples were processed as described above for xanthoma material, and specific activities of tissue cholesterol were calculated.

\section{RESULTS}

Analysis of serum cholesterol specific activity. Serum cholesterol concentrations remained stable during the experiment. The average levels and standard deviations for the four patients are included in Table I. The weights of the patients remained constant to within $3-4 \mathrm{lb}$, and the results of the physical examinations and the monitoring laboratory tests were unchanged. The specific activity of total serum cholesterol decayed in a curvilinear fashion on a semilog plot during the initial 5-10 wk after injection of the tracer. To evaluate statistically the long-term flattening behavior of the decay curves, a least-square curve fitting method was developed by one of us (S. L.). For each choice of the possible location of 2 or 3 exponentials a least-squares fit of the data to a double exponential curve and a triple exponential curve were obtained using an XDS Sigma VII digital computer. The computer was programmed to choose the best 2- and 3-exponential curve fits of all these existing possibilities, by selecting the ones with the smallest standard deviation. The standard deviations of the logarithms were computed and compared using the $F$ test. The standard deviation of the 3-exponential fit was significantly smaller than the standard deviation of the 2-exponential fit at the $0.1 \%$

TABLE II

Net Counts of Radioactivity Accumulated on Serum Samples and Coefficient of Variation of the Observed Sample Counting Rates Obtained From the Last Serum Sample in Each Patient

\begin{tabular}{lccc}
\hline Patient & Time & $\begin{array}{c}\text { Counts/ } \\
100 \text { min* }\end{array}$ & Vs $\ddagger$ \\
\hline & $w k$ & & $\%$ \\
A. K. & 53 & 39,200 & 0.52 \\
N. A. & 63 & 26,600 & 0.64 \\
T. B. & 63 & 44,400 & 0.47 \\
A. W. & 63 & 21,100 & 0.73 \\
\hline
\end{tabular}

* Net counts (total minus background) of radioactivity accumulated on serum samples (rounded to nearest hundred). The average background was 1200 counts $/ 100 \mathrm{~min}$. $\ddagger$ Coefficient of variation of observed sample (net) counting rate $(\%)(11)$.

$$
\mathrm{V}_{\mathrm{S}}=\frac{\left(\mathrm{N}_{\mathrm{c}} \mathrm{t}_{\mathrm{b}}^{2}+\mathrm{N}_{\mathrm{b}} \mathrm{t}_{\mathrm{c}}^{2}\right)^{3}}{\mathrm{~N}_{\mathrm{c}} \mathrm{t}_{\mathrm{b}}-\mathrm{N}_{\mathrm{b}} \mathrm{t}_{\mathrm{c}}}
$$

where $N_{c}=$ counts accumulated during time $t_{b}$ in the measurement of background and sample combined; $\mathrm{N}_{\mathrm{b}}=$ counts accumulated during time $t_{b}$ in the measurement of background; $t_{b}=$ counting time when background is measured; and $t_{c}=$ counting time when sample and background together are measured. 


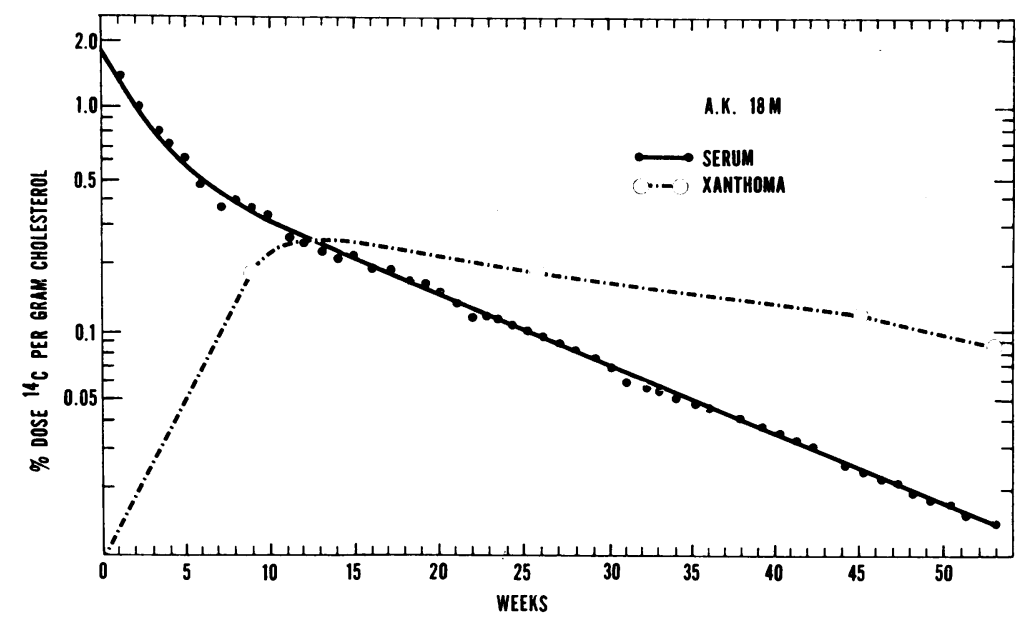

FigURE 1 Semilogarithmic plot of the long-term decay of total serum cholesterol specific activity (solid line) and xanthoma cholesterol specific activity (broken line).

level $(P<0.001)$ in patient N. A. $(\mathrm{F}=3.13)$. Although in patients $A$. W. and $A$. $K$. the ratio of the standard deviations was not statistically significant as measured by the $F$ test $(F=1.56$ and 1.03 respectively), the standard deviations were smaller for the 3-exponential fit than for the 2-exponential fit in these two subjects. For Patient T. B. the 2-exponential fit was found sufficient to represent the data $(F=0.92)$. The slowest exponential, if any, appeared about $35 \mathrm{wk}$ after pulse labeling. Of the exponential curve fitting half times $\left(t_{1}\right)$ the slowest half-time $\left(t_{1}\right)_{3}$ ranged from 69 to 108 days, the next fastest half-time $\left(t_{1}\right)_{2}$ ranged from 17 to 39 days, and the fastest half-time $\left(t_{1}\right)_{1}$, where able to be fitted, ranged from 8 to 10 days (Table III).

The results of the data analysis obtained in the four patients are included in Table I. The calculated average value for input rates $\left(I_{T}\right.$ ) (sum of dietary and biosynthesized cholesterol) was $1.3 \mathrm{~g} /$ day in the four patients. The average size of the rapidly miscible pool of cholesterol ( $\mathrm{Ma}_{\mathrm{a}}$ ) was $56 \mathrm{~g}$. The average value for M (total exchangeable mass of cholesterol) was $117 \mathrm{~g}$, and for $\mathrm{M}-\mathrm{M}_{\mathrm{a}}$ (remaining exchangeable mass of cholesterol) $61 \mathrm{~g}$. The average value of $\bar{t}_{p}$ (average transit time of cholesterol) was 91 days (Table I).

Analysis of xanthoma specific activity. Although the number of data points on xanthoma specific activity was limited to four points in each patient, several facts are clearly apparent. During the initial 5-10 wk after pulse labeling, the specific activity of xanthoma cholesterol increased rapidly, while specific activity in the serum decreased (Figs. 1-4). The two curves crossed over approximately at the beginning of the slow portion of the serum decay curves (8-10 wk) in three of four patients. In the fourth subject (N. A.) the crossover occurred later (beginning of the slower exponential?) (Fig. 2). After crossover, the specific activity of xanthoma cholesterol remained consistently above and became severalfold higher than the serum cholesterol specific activity. Table IV includes a comparison between serum and xanthoma cholesterol specific activities. 9 wk after the injection of tracer the average

TABLE III

Exponential Parameters in the Four Patients Studied

\begin{tabular}{|c|c|c|c|c|c|c|c|c|}
\hline Patient & $a_{1} *$ & $a_{2} *$ & $\mathbf{a}_{3} *$ & $\left.\left.\mathrm{t}_{1}\right)\right)_{1}^{*}$ & $\left.\mathrm{t}_{1}\right) 2^{*}$ & $\mathrm{t}_{3} / \mathrm{s}^{*}$ & $\left.t_{\frac{1}{3}}\right)_{x} \ddagger$ & $100 k \times$ \\
\hline & & $(100 \mathrm{~g})$ & & \multicolumn{4}{|c|}{ days } & $\% / d a y$ \\
\hline A. $\mathrm{K}$. & 1.06 & 0.202 & 0.550 & 9.58 & 36.3 & 68.9 & 130 & 0.53 \\
\hline N. A. & 2.10 & 0.440 & 0.240 & 8.38 & 38.9 & 108 & 385 & 0.18 \\
\hline T. B. & 0 & 0.980 & 0.351 & - & 16.6 & 108 & 143 & 0.49 \\
\hline A. W. & 1.19 & 0.288 & 0.289 & 9.51 & 35.7 & 87.7 & 144 & 0.48 \\
\hline
\end{tabular}

*Exponential parameters obtained by "peeling off" serum kinetic data.

$\ddagger$ Xanthoma decay half-life, straight line through last two points on semi-log plot.

$\S 100 k_{\mathrm{x}}=69.3 / \mathrm{t}_{\mathrm{l}) \mathrm{x}}=$ exponential rate constant of xanthoma exchangeable cholesterol. 


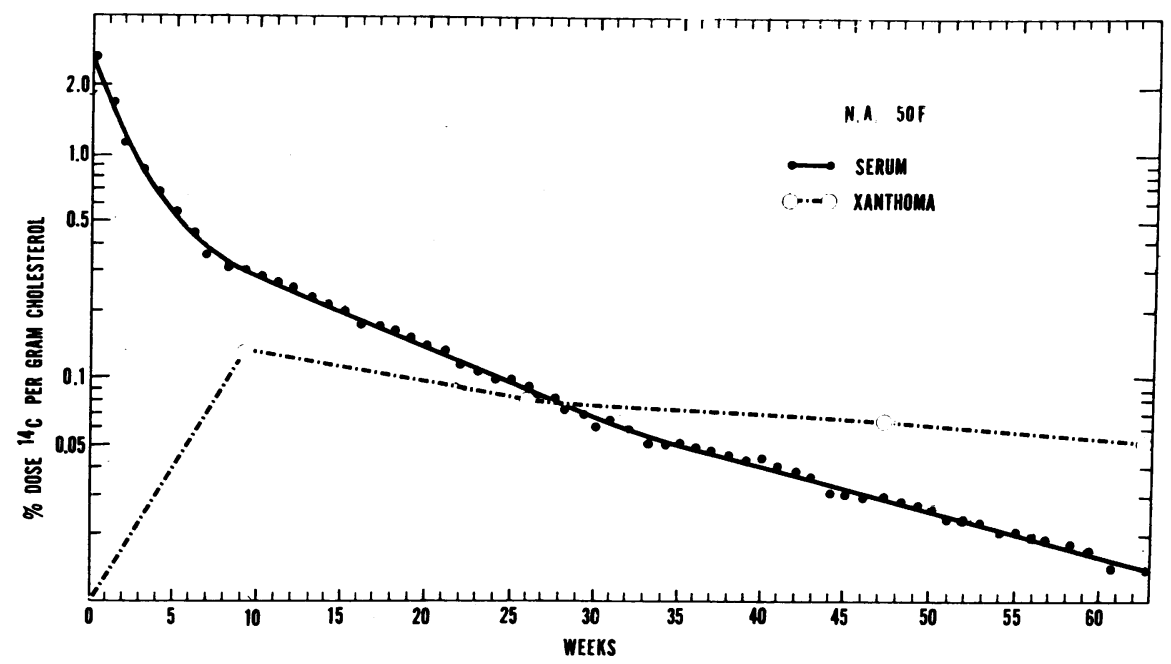

Figure 2 See legend to Fig. 1.

specific activity of xanthoma cholesterol was $45 \%$ of serum specific activity; at 26 wk average xanthoma specific activity was 1.79 times higher than serum, and at $47 \mathrm{wk}$ and $63 \mathrm{wk}$ this average ratio increased to 3.8 and 4.8 respectively. It is not evident from Figs. $1-4$ whether the final xanthoma slope would approach the existing serum slope with increasing time or vice versa. It was considered of interest to ask what changes would result in $I_{T}$ and $M$ in the admittedly extreme limiting case in which the serum slope changed to the xanthoma slope at the maximum measurement time and remained unchanged thereafter. Application of equations 1, 3, and 5 to the modified serum curve resulted in only insignificant changes in $I_{T}$ (average $-0.03 \mathrm{~g} /$ day) and in $\mathrm{M}$ for patients A. K., T. B., and A. W. (average 10 $\mathrm{g}$ ). For patient $\mathrm{N}$. A. the value of $\mathrm{M}$ increased by $64 \mathrm{~g}$ $(65 \%)$ which may be significant.
The exponential rate constant corresponding to the final xanthoma half-life, as estimated from the last two points on the xanthoma decay curve, is given by

$$
\left.100 k_{\mathrm{x}}=69.3 / \mathrm{t}_{\frac{1}{2}}\right)_{\mathrm{x}} ;(\% / \text { day }) \text {. }
$$

The values derived from this equation for the four patients are included in Table III. In three of the four subjects the value of $100 k_{x}$ of xanthoma cholesterol was about $0.5 \%$ /day. In the fourth patient (N. A.) this figure was $0.18 \%$ /day (Table III).

Analysis of tissue specific activity. The data on tissue specific activities of patient A. K. are included in Table V. The tissue of highest specific activity $53 \mathrm{wk}$ after injection of tracer was xanthoma. Aortic cholesterol, both obtained from aortic atheromas and from areas of the aorta without visible cholesterol deposits showed specific activities more than 3-fold that of serum.

TABLE IV

Specific Activity of Serum and Xanthoma Cholesterol at the Time of Biopsies

\begin{tabular}{|c|c|c|c|c|c|c|c|c|c|c|c|c|}
\hline \multirow[b]{2}{*}{ Patient } & \multicolumn{3}{|c|}{9 wk } & \multicolumn{3}{|c|}{26 wk } & \multicolumn{3}{|c|}{$47 \mathrm{wk}$} & \multicolumn{3}{|c|}{$63 \mathrm{wk}$} \\
\hline & Serum & $\begin{array}{l}\text { Xan- } \\
\text { thoma }\end{array}$ & $\begin{array}{c}\text { Xan- } \\
\text { thoma/ } \\
\text { serum }\end{array}$ & Serum & $\begin{array}{l}\text { Xan- } \\
\text { thoma }\end{array}$ & $\begin{array}{l}\text { Xan- } \\
\text { thoma/ } \\
\text { serum }\end{array}$ & Serum & $\begin{array}{l}\text { Xan- } \\
\text { thoma }\end{array}$ & $\begin{array}{c}\text { Xan- } \\
\text { thoma/ } \\
\text { serum }\end{array}$ & Serum & $\begin{array}{l}\text { Xan- } \\
\text { thoma }\end{array}$ & $\begin{array}{c}\text { Xan- } \\
\text { thoma/ } \\
\text { serum }\end{array}$ \\
\hline & $d p m / g$ & $i p m / g$ & & $d p m / g$ & $d p m / g$ & & $d p m / g$ & $d p m / g$ & & $d p m / g$ & $d p m / g$ & \\
\hline & $\times 10^{3}$ & $\times 10^{3}$ & & $\times 10^{3}$ & $\times 10^{3}$ & & $\times 10^{3}$ & $\times 10^{3}$ & & $\times 10^{3}$ & $\times 10^{3}$ & \\
\hline A. $\mathrm{K}$. & 648 & 333 & 0.51 & 164 & 343 & 2.09 & $41.7^{*}$ & $215^{*}$ & $5.17^{*}$ & $25.4 \ddagger$ & $155 \ddagger$ & $6.12 \ddagger$ \\
\hline N. A. & 554 & 242 & 0.44 & 155 & 147 & 0.95 & 54.5 & 113 & 2.08 & 24.6 & 92.4 & 3.75 \\
\hline T. B. & 523 & 330 & 0.63 & 197 & 334 & 1.69 & 76.3 & 169 & 2.23 & 40.1 & 96.8 & 2.41 \\
\hline A. W. & 475 & 108 & 0.23 & 130 & 318 & 2.43 & 35.6 & 204 & 5.74 & 17.4 & 119 & 6.84 \\
\hline Average & & & 0.45 & & & 1.79 & & & 3.80 & & & 4.78 \\
\hline
\end{tabular}

* $45 \mathrm{wk}$.

$\ddagger 53 \mathrm{wk}$. 


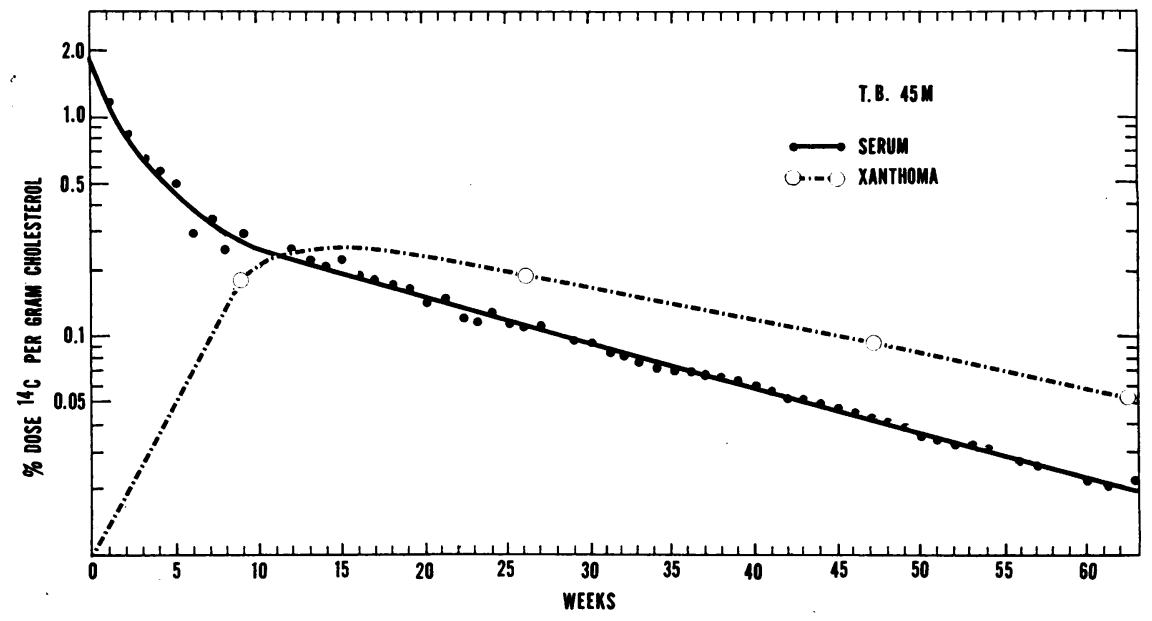

FIGURE 3 See legend to Fig. 1.

Subcutaneous fat and spleen contained cholesterol specific activities almost 2 -fold that of serum. In the remaining organs examined, the ratio was close to unity (Table V). The exception was brain cholesterol with a specific activity of only $19 \%$ of that of serum (Table V).

Although the preceding single terminal values on the respective tissue specific activity curves suggest a

TABLE V

Cholesterol Content and Tissue Specific Activity of Cholesterol in Patient A. K. 53 wk after Pulse Labeling

\begin{tabular}{lccc}
\hline \multicolumn{1}{c}{ Tissue } & $\begin{array}{c}\text { Cholesterol } \\
\text { concentration } \\
\text { per } 100 \mathrm{~g} \\
\text { wet tissue }\end{array}$ & $\begin{array}{c}\text { Specific } \\
\text { activity }\end{array}$ & $\begin{array}{r}\text { Specific } \\
\text { activity, } \\
\text { tissue/ } \\
\text { serum }\end{array}$ \\
\hline Serum & $m g$ & $\begin{array}{c}d p m / g \\
\text { cholesterol }\end{array}$ & \\
Xanthoma* & 742 & 25.4 & 1.00 \\
Aortic atheroma & 7397 & 155.0 & 6.12 \\
Aortic wall & 4732 & 79.3 & 3.12 \\
Fat (sub- & 447 & 79.1 & 3.12 \\
$\quad$ cutaneous) & & & \\
Spleen & 260 & 49.9 & 1.97 \\
Heart muscle & 872 & 46.1 & 1.82 \\
Liver & 200 & 36.6 & 1.44 \\
Kidney & 978 & 32.9 & 1.30 \\
Skin and sub- & 355 & 32.8 & 1.29 \\
$\quad$ cutaneous tissue & & & \\
Small intestine & 260 & 32.7 & 1.29 \\
Sceletal muscle & 357 & 32.0 & 1.26 \\
Large intestine & 200 & 29.9 & 1.18 \\
Brain & 673 & 23.6 & 0.93 \\
& 2711 & 4.9 & 0.19 \\
\hline
\end{tabular}

* Average of samples obtained from left elbow, left knee, and left Achilles tendon (see text). grouping of tissues with respect to rapidity of exchange with serum cholesterol, compartmental analysis does not yield more precise conclusions. It was reported (7) that cholesterol in each apparently homogeneous tissue or organ does not belong solely to a single compartment (as determined by analysis of the serum curve) but rather is distributed among all the compartments. This consideration would make it impossible to determine from a single known point on a tissue specific activity curve, plus the known serum specific activity curve, the apportionment of the tissue cholesterol among the compartmental pools indicated by the serum kinetics.

The brain was washed three times and kept in buffered formalin for $4 \mathrm{wk}$. A randomly chosen sample (by the pathologist) was washed thoroughly several times with normal saline before processing for the determination of specific activity (see Methods). Although the possibility of trace contamination by serum could not be completely ruled out, it was felt that a fairly reliable estimate of fractional turnover rate of brain cholesterol could be made. It was assumed that brain cholesterol specific activity increased linearly from 0 at time zero to the observed value of $\mathrm{W}_{\mathbf{B R}}\left(\mathrm{t}_{\mathrm{m}}\right)=0.19$ $\times 0.014=0.0027(100 \mathrm{~g})^{-1}$ at $\mathrm{t}=53$ wk. If labeled brain cholesterol is assumed to exchange with serum cholesterol by first-order kinetics, it can be shown that the fractional turnover rate of brain cholesterol is given by

$$
\frac{r_{B R}}{M_{B R}}=\frac{w_{B R}\left(t_{m}\right)}{\int_{0}^{t m} w(t) d t-\int_{0}^{t m} w_{B R}(t) d t}
$$

where $r_{\mathbf{B R}}(\mathrm{g} /$ day) is exchange rate between exchangeable brain cholesterol and serum cholesterol and $\mathbf{M}_{\mathbf{B R}}$ (g) is the mass of exchangeable brain cholesterol. The 
area integral of the serum specific activity per unit dose in equation 10 was evaluated from the exponential curve-fit data for A.K. as $78.6 \mathrm{~d} / 100 \mathrm{~g}$ (not significantly different from a point-by-point evaluation). The area integral of the brain specific activity per unit dose in equation 9 was evaluated by the assumption of linear variation from 0 at $t=0$ to 0.0027 at $t=53$ wk as $0.50 \mathrm{~d} / 100 \mathrm{~g}$. Substituting the preceding results in equation 9 yields the fractional turnover rate of brain cholesterol as

$$
\frac{r_{B R}}{M_{B R}}=\frac{0.0027}{78.6-0.50}=0.35 \times 10^{-4}=1.3 \% / y r
$$

\section{DISCUSSION}

The slow slope of the long-term decay of serum cholesterol specific activity clearly proceeded at more than a single exponential rate in one of four patients of the present study. For two additional patients a leastsquares curve fitting computer analysis showed that a better fit was obtained by 3 exponentials, but the difference between 2- and 3-exponential curve fits was not statistically significant. In the remaining patient a 2-exponential curve fit sufficed. The observed counts on the last data points of the curves were sufficiently high so that counting error was negligible for present purposes (Table II). The patients were in an apparent steady state of cholesterol metabolism throughout the study; the level of serum lipids showed variations usually seen in this type of patient (see standard deviations in Table I). The reproducibility of the recovery of radioactive cholesterol from human serum in this laboratory was periodically checked and was found to be within $\pm 4 \%$ of error.

In a previous paper from this laboratory (6) a similar flattening of long-term decay curves was reported in three of seven patients studied. In addition, two of the subjects in this group exhibited a possible flattening of the decay curves, whereas the two remaining patients showed monoexponential behaviour of serum cholesterol specific activity (6). The patients in the present study had markedly elevated serum cholesterol levels and xanthomatosis (Table I), whereas in our previous study three of the subjects who showed flattening of the decay curves had serum lipid levels regarded as normal (6). Although these data may indicate the existence of several types of long-term handling of cholesterol independent of the heights of serum lipid levels, it is quite possible that the appearance of the progressive flattening of the slow slope of the curves, if any, depends merely on the duration of observation.

The physiologic explanation of the flattening of the serum kinetic curve is at least qualitatively understandable in compartmental terms. During the initial period after pulse labeling, the rapid decay of serum cholesterol specific activity is thought to be due to the distribution of tracer into the rapidly exchangeable cholesterol of body tissues. The unlabeled cholesterol flowing into the serum from the tissues during this exchange process, together with the inflow of newly synthesized and dietary cholesterol (both unlabeled) into the serum, account for the rapid dilution of the injected radioactivity. At later times the cholesterol flowing into the serum from rapidly exchanging tissues is labeled at a specific activity somewhat higher than the serum so that this source of dilution of serum specific activity no longer obtains. However, the dilution process continues with respect to the slower exchanging cholesterol and it may be revealed by the next slower exponential decay. rate of the serum curve, etc.

In the calculation of the derived parameters, the flattening of the curves, if any, directly influenced the derived value of input rate $\left(I_{T}\right)$ (sum of dietary and biosynthesized cholesterol ; equivalent to $P R=$ production rate in reference 1 ). Since $I_{T}$ is the reciprocal of the area under the curve (5), further flattening results in an increase of this area, and thus in an inversely proportional decrease of the value of $I_{T}$. Grundy and Ahrens (3) found slightly but consistently higher values of calculated production rates using the two-pool model as compared to values obtained by sterol balance through chemical analysis in the same subjects. As previously suggested (6), a possible explanation for this difference was the increment of area under the specific activity decay curves for the first few days after injection, which would be missed by the 2 exponentials. The decrease in the value of $I_{T}$ due to the flattening of the long-term decay curves (if any) may also contribute to the explanation of this discrepancy.

The xanthoma kinetic data, although sparse, appear compatible with the precursor-product relationship (15, 16) of xanthoma curve with serum curve in three of the patients studied (Figs. 1, 3, and 4), that is, the data suggest that the maximum specific activity of xanthoma cholesterol occurred approximately at the intersection of xanthoma and serum curves. Satisfaction of this relationship indicates that the xanthoma cholesterol pool exchanges directly with serum cholesterol (no intermediate pool between these two pools), and that no local production of xanthoma cholesterol occurs (which by definition would not be initially accessible to labeling by the tracer injection). In patient N.A. (Fig. 2) the xanthoma curve appears to intersect the serum curve much later than at the maximum of the xanthoma curve, thus violating the precursor-product rule. The final exponential slope of the xanthoma curve in this patient $(0.18 \% /$ day $)$ was also markedly different from that of the other three patients (approximately $0.5 \% /$ day; Table III). An at- 


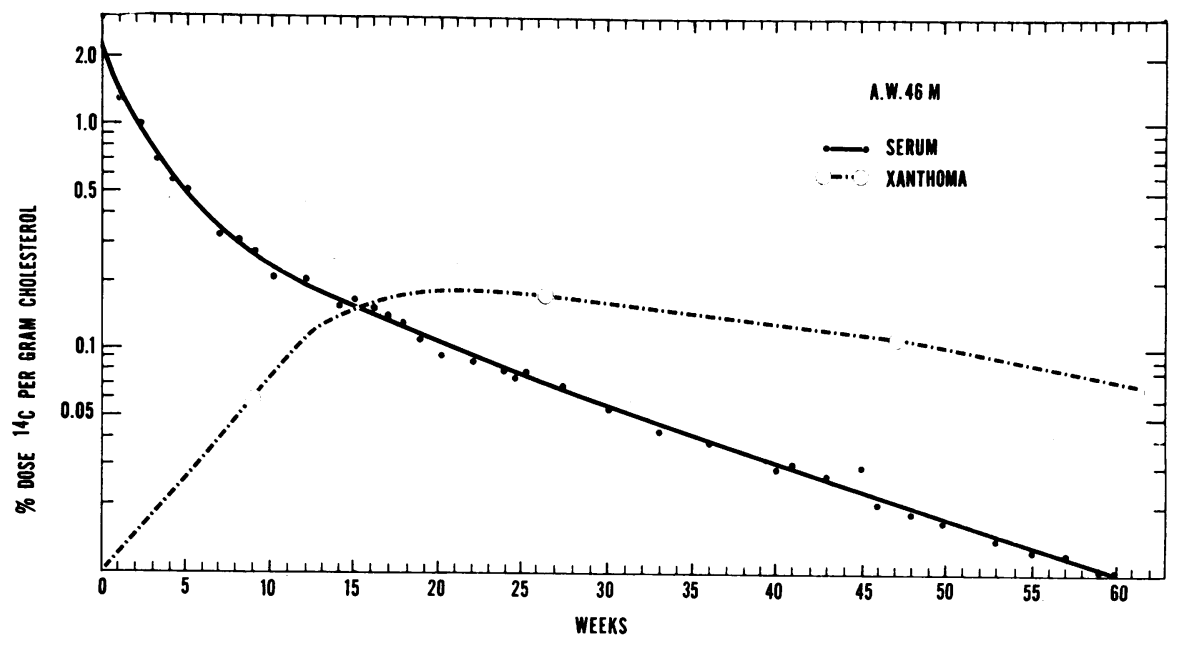

Figure 4 See legend to Fig. 1.

tempt to understand the different behavior of the xanthoma kinetics of patient N. A. was made as follows. The area under the xanthoma curve was obtained by the trapezoidal rule for the four observed points plus exponential extrapolation of the last two observed points. This area was less than the area under the serum curve by $12,28,14$, and $10 \%$, respectively, for patients $\mathrm{A}$. K., N. A., T. B., and A. W. It has recently been shown (17-19) that in single input systems the area under the specific activity per unit dose curve measured anywhere in the system should be the same, as well as equal to the reciprocal of the systemic input rate of traced substance. The present comparison shows an approximately $12 \%$ deficit for three patients and a $28 \%$ deficit for patient N. A. Two possibilities are suggested in explanation. The first possibility is that the area under the xanthoma curve has been systematically underestimated due to sparcity of data points and possibly by missing the maximum specific activity point for N. A. Each of the biopsies were taken from tendon xanthomas, three from the extensor surface of the left hand and the second biopsy from the extensor surface of the right hand. The histology, age, and blood circulation of these xanthomas may have been different. The second possibility is that the areas are correct and the labeling of the xanthomas is homogeneous but that we are dealing with a multiple input system (18), that is, there is a local production rate of xanthoma cholesterol which is not immediately labeled by the intravenous injection of tracer cholesterol. Two additional theoretical possibilities can be ruled out, namely that the anomalous appearance of the xanthoma curve of $\mathrm{N}$. A. can be explained, first by unusually low rate of exchange between xanthoma and serum cholesterol, or second by inhomogeneity of the xanthoma cholesterol pool. The first case would yield a xanthoma curve which crosses the serum at a lower specific activity but which still obeys both the precursor-product rule $(15,16)$ and the equal area rule $(17-19)$. The second case would yield a xanthoma curve which violates the precursor-product rule but which still obeys the equal area rule (the precursor-product rule implies the equal area rule but not vice versa). The xanthoma curve of $\mathrm{N}$. A. indicates violation of both the precursor-product rule and the equal area rule. Although previous evidence indicates that only slight amounts of cholesterol may be synthesized in situ (20), local production of cholesterol in xanthomas (possibly combined with an inhomogeneous pool) may represent the most plausible hypothesis to explain the behavior of the xanthoma curve of patient $\mathrm{N}$. A. If this explanation is correct, then the data indicate that the local production of xanthoma cholesterol of patient N. A. is markedly increased as compared to that of the other three subjects. On careful review of the clinical course of this patient there was nothing unusual noted at anytime during the experiment. Finally it must be pointed out that N. A. was the only female of the four patients in this study. Whether the atypical behavior of xanthoma data was due to the sex difference cannot be ascertained on the basis of one case, of course.

After the crossover of serum and xanthoma curves, the specific activity of xanthoma cholesterol remained consistently above that of serum (Table IV, Figs. 1-4). The ratio of specific activity increased after pulse labeling from an average of 0.45 at 9 wk (Table IV) to an average of 4.78 at the end of the experiment. Moutafis and Myant (21) took biopsies of skin xanthoma in two patients after pulse labeling. In one of their patients the specific activity of skin xanthoma cholesterol was about 6 times as high as that of plasma cholesterol, 244 and 255 days after administration of the tracer. The present 
data are in general agreement. In a recent study Quintão, Grundy, and Ahrens (22) showed that specific activities of cholesterol in biopsied muscle, skin, adipose tissue, and tuberous xanthomas in one patient with hypercholesterolemia failed to attain isotopic equilibrium with plasma 40 days after plateau of specific activity of plasma cholesterol had been reached (using daily oral "steady-state" labeling). The results in the present study are in agreement with these data. On inspection of Figs. $1-4$, it is apparent that at the 6 wk level (about 40 days) the specific activity of xanthoma cholesterol (and presumably cholesterol in other slowly turning over tissues) was markedly below that of serum, and was still in the ascending phase.

Table I includes the values derived from the inputoutput analysis of serum decay curves. It must be emphasized that the data derived from these calculations and from the xanthoma curves are approximate and express orders of magnitude rather than exact figures. Should available data on the serum decay curves eventually include several hundred weeks, and the xanthoma curves a significantly larger number of biopsies, more exact analyses could be made. With presently available methods, however, this type of experiment would demand the administration of prohibitively large doses of radioactivity and frequent biopsies of unjustifiable discomfort to the patients. Nonetheless, it is felt that within the framework of these qualifications, the general validity of the data in the present study is safely acceptable, in spite of the inherent error due to the scarcity of data points. The calculation of the area under the xanthoma specific activity curves and the demonstration of approximate compliance with a single input system of the xanthoma data in three of the four patients lends strong support to these arguments.

Table $\mathrm{V}$ includes data on the cholesterol content of tissues (per $100 \mathrm{~g}$ ) of patient A. K., who had severe hypercholesterolemia and xanthomatosis. The tissue cholesterol content in this patient was markedly increased in most organs studied, as compared to data reported by Khan, Cox, and Asdel in patients with normal or moderately elevated serum cholesterol levels (23). Table V indicates that 53 wk after pulse labeling the specific activity of tissue cholesterol exceeded severalfold that of serum in a number of organs. A notable exception was the brain with a specific activity of $19 \%$ that of serum. The data suggest that there is a very effective blood-brain barrier for cholesterol with an estimated yearly turnover rate of $1.3 \%$ of brain cholesterol, or about once in a lifetime (once in $77 \mathrm{yr}$ ).

Field, Swell, Schools, and Treadwell (24) reported the specific activity of tissue cholesterol in eight patients who came to autopsy 2.5-137 days after administration of tracer. Chobanian and Hollander (25) studied the equilibration of tracer cholesterol between blood and tissues in nine subjects who died 1-226 days after pulse labeling. In both of these reports specific activities of serum and tissue cholesterol remained approximately equal for the duration of the study after equilibration was reached. The present data differ with these results. The reason for this discrepancy is not quite clear. Avigan, Steinberg; and Berman reported (26) that in rats and rabbits specific activities of cholesterol in most body tissues studied exceeded markedly that of serum. Wilson obtained similar results in the baboon (7). It has been suggested (7) that one of the reasons for the discrepancy encountered in previous studies conducted in humans was the severely debilitating terminal diseases of the study subjects. Most of them had terminal cancer, and the disease may have interfered with feeding (possible terminal intravenous feeding), cholesterol absorption, and biosynthesis. These factors could influence a number of parameters and would probably significantly alter the steady-state condition. The patient in the present study died suddenly of a massive myocardial infarction and was in the apparent steady state up to the time of death.

In a previous paper from this laboratory (6) it was reported that the sizes of the rapidly miscible pool of cholesterol $\left(\mathrm{M}_{2}\right)$ and total exchangeable body mass of cholesterol (M) were significantly higher in patients with hypercholesterolemia as compared to subjects with normal serum lipids. The group of patients with hypercholesterolemia consisted of four subjects with relatively moderate elevations of serum cholesterol level and a fifth with marked hypercholesterolemia and xanthomatosis (patient H. Z., Table I in reference 6). The results of the present analysis were compared to the data of the patients in reference 6 by grouping subject H. Z. together with the present patients in the calculation of the average values. Table VI includes the comparison of derived parameters in a total of 15 patients ( 11 from reference 6); six had normal serum lipid levels (group A), four had moderate hypercholesterolemia (and normal triglycerides) (group B), and five had marked hypercholesterolemia (type II hyperlipoproteinemia) and xanthomatosis (group $\mathrm{C}$ ). The table also includes average values calculated as per kilogram of body weight. The average values of $I_{T}$ (input rates, the sum of dietary and biosynthesized cholesterol) (equivalent to production rates, $\mathrm{PR}$, in reference 1) were not significantly different, except for the comparison of groups A and C. As discussed previously (6) it was concluded that the differences in the values of input rates were not biologically significant. This statement is in agreement with the data of others $(1,4,27)$, when measurements were made by different methods (chemical sterol balance, compartmental analysis, isotopic balance, etc.), in 
TABLE VI

Comparison of Turnover and Body Masses of Cholesterol (Average $\pm \mathrm{SD}$ ) in 15 Patients Studied in This Laboratory, with Normal Serum Lipids, Moderate Hypercholesterolemia (Type II) and Marked Hypercholesterolemia (Type II), and Xanthomatosis*

\begin{tabular}{|c|c|c|c|c|c|c|c|c|c|}
\hline \multirow[b]{2}{*}{$\begin{array}{l}\text { Number of patients and } \\
\text { reference }\end{array}$} & \multicolumn{2}{|c|}{$\begin{array}{l}\text { (A) } \\
\text { Normal serum } \\
\text { lipids }\end{array}$} & \multicolumn{2}{|c|}{$\begin{array}{c}(B) \\
\text { Moderate hyper- } \\
\text { cholesterolemia }\end{array}$} & \multicolumn{2}{|c|}{$\begin{array}{l}(\mathrm{C}) \\
\text { Marked hyper- } \\
\text { cholesterolemia } \\
\text { and xanthomatosis }\end{array}$} & \multirow[t]{2}{*}{$\begin{array}{l}\text { Difference } \\
\text { of } \\
\text { (A) and (B) }\end{array}$} & \multirow[t]{2}{*}{$\begin{array}{l}\text { Difference } \\
\text { of } \\
\text { (A) and (C) }\end{array}$} & \multirow[t]{2}{*}{$\begin{array}{l}\text { Difference } \\
\text { of } \\
\text { (B) and (C) }\end{array}$} \\
\hline & $\begin{array}{l}6 \text { pati } \\
\text { (ref }\end{array}$ & $\begin{array}{l}\text { tts } \\
\text { rence } 6)\end{array}$ & $\begin{array}{l}4 \text { patie } \\
\text { (ref }\end{array}$ & $\begin{array}{l}\text { ts } \\
\text { ence 6) }\end{array}$ & $\begin{array}{l}5 \text { patie } \\
(1 \mathrm{p} \\
\text { refer } \\
4 \text { pa } \\
\text { pres }\end{array}$ & $\begin{array}{l}\text { ts } \\
\text { tient in } \\
\text { nce } 6 ; \\
\text { ients in } \\
\text { nt study) }\end{array}$ & & & \\
\hline $\begin{array}{l}\text { Average total serum } \\
\text { cholesterol, } \mathrm{mg} / 100 \mathrm{ml} \\
\text { Average serum } \\
\text { triglycerides, } \mathrm{mg} / 100 \mathrm{ml}\end{array}$ & $\begin{array}{r}228 \\
99\end{array}$ & $\begin{array}{l} \pm 16 \\
\pm 14\end{array}$ & $\begin{array}{l}298 \\
105\end{array}$ & $\begin{array}{l} \pm 19 \\
\pm 19\end{array}$ & $\begin{array}{l}601 \\
116\end{array}$ & $\begin{array}{l} \pm 59 \\
\pm 25\end{array}$ & & & \\
\hline $\begin{array}{l}\mathrm{I}_{\mathrm{T}} \neq g / d a y \\
\mathrm{M}_{\mathrm{a}}, g \\
\mathrm{M}, \mathrm{g} \\
\mathrm{M}-\mathrm{M}_{\mathrm{a}}, g \\
\overline{\mathrm{t}}_{\mathrm{p}}, \text { days }\end{array}$ & $\begin{array}{l}1.0 \\
28 \\
76 \\
50 \\
79\end{array}$ & $\begin{array}{l} \pm 0.20 \\
\pm 16 \\
\pm 13 \\
\pm 8 \\
\pm 12\end{array}$ & $\begin{array}{r}1.2 \\
45 \\
116 \\
71 \\
95\end{array}$ & $\begin{array}{l} \pm 0.22 \\
\pm 21 \\
\pm 11 \\
\pm 23 \\
\pm 23\end{array}$ & $\begin{array}{r}1.3 \\
56 \\
128 \\
71 \\
98\end{array}$ & $\begin{array}{l} \pm 0.14 \\
\pm 12 \\
\pm 29 \\
\pm 24 \\
\pm 20\end{array}$ & $\begin{array}{c}0.27 \S \\
17(61 \%) \S \\
38(49 \%)^{* *} \\
11(42 \%) \S \\
16 \S\end{array}$ & $\begin{array}{c}0.29 \| \\
28(100 \%) \text { ๆ } \\
50(64 \pm) \rrbracket \\
21(42 \%) \S \\
19 \S\end{array}$ & $\begin{array}{c}0.02 \S \\
11(39 \%) \S \\
12(10 \%) \S \\
0 \\
3 \S\end{array}$ \\
\hline $\begin{array}{l}\mathrm{I}_{\mathrm{T}}, \mathrm{g} / \text { day per } k g \\
\mathrm{M}_{\mathrm{a}}, \mathrm{g} / \mathrm{kg} \\
\mathrm{M}, \mathrm{g} / \mathrm{kg} \\
\mathrm{M}-\mathrm{M}_{\mathrm{a}}, g / k g\end{array}$ & & $\begin{array}{l}016 \\
43 \\
20 \\
78\end{array}$ & & $\begin{array}{l}017 \\
59 \\
54 \\
96\end{array}$ & & $\begin{array}{l}021 \\
88 \\
03 \\
15\end{array}$ & $\begin{array}{l}- \\
(27 \%) \S \\
(22 \%) \| \\
(19 \%) \S\end{array}$ & $\begin{array}{l}(51 \%)^{* *} \\
(41 \%) \| \\
(32 \%) \S\end{array}$ & $\begin{array}{l}- \\
(33 \%) \S \\
(24 \%) \S \\
(17 \%) \S\end{array}$ \\
\hline
\end{tabular}

* The data calculated as per kilogram of body weight for the three groups are also shown.

$\ddagger$ See definitions in footnote to Table I.

$\S$ Statistically not significant.

$\| P<0.05$.

I $P<0.01$.

** $P<0.001$.

comparing normal and hypercholesterolemic subjects. The average values of the size of the rapidly miscible pool of cholesterol $\left(\mathrm{Ma}_{\mathrm{a}}\right)$ (pool A from reference 1) showed marked differences between the three groups of patients. The absence of statistical significance between groups A and B and groups B and C was probably due to the small number of participants and relatively large standard deviations (Table VI). The difference of average values of $M_{a}$ between patients with normal serum lipids (group A) and with moderate hypercholesterolemia (group B) was $61 \%$. The difference of the average size of $\mathrm{M}_{\mathrm{a}}$ between group $B$ and group $C$ (patients with marked hypercholesterolemia) was $39 \%$. The mass of serum cholesterol $\left(M_{s}\right)$ is included in the value of $M_{a}$. The contribution of $\mathrm{M}_{\mathrm{s}}$ (calculated from standard physiologic tables) to the average value of $\mathrm{Ma}_{\mathrm{a}}$ was less than $20 \%$ of the total mass in each group, showing an impressive difference in the size of the rapidly miscible pool of tissue cholesterol among the three groups. The average value of total exchangeable body mass of cho- lesterol (M) was significantly higher in patients with moderate and marked hypercholesterolemia than in subjects with normal serum lipids. The differences were rather impressive: $38 \mathrm{~g}$ and $50 \mathrm{~g}$, respectively. The respective per cent increments were $49 \%$ and $64 \%$ (Table VI). When the data were calculated as per kilogram of body weight, the per cent differences were smaller, but the pattern of the statistical significance of differences among the three groups remained essentially unchanged. The calculated values of $M$ (total exchangeable body mass of cholesterol) showed no significant difference between patients with moderate hypercholesterolemia (group B) and marked hypercholesterolemia and xanthomatosis (group C). This conclusion is further emphasized by the comparison of the average values of $\mathrm{M}-\mathrm{M}_{\mathrm{a}}$ (the remaining exchangeable mass of cholesterol) which were virtually identical for the two groups (Table VI). There may be several possible explanations of this. The first is the possibility that the total carcass of patients with marked hypercholesterol- 
emia does not contain a significantly higher mass of cholesterol than that of patients with moderate hypercholesterolemia. The very high serum levels and tissue deposits in xanthomas may be a distributional anomaly. The second possibility is that with the present length of the experiments (15-63 wk including data of reference 6 ), most of the body mass of cholesterol in patients with moderate hypercholesterolemia (group B) may have been exchanged, whereas in patients with marked hypercholesterolemia and xanthomatosis (group C) the exchange was not completed. This explanation is also supported by the xanthoma specific activity data. The third possibility to explain this discrepancy is that in the present calculations it was assumed that all biosynthesized cholesterol enters directly the rapidly miscible pool $\left(\mathrm{M}_{2}\right)$ and that the rate of input anywhere else in the body was negligible (5). It is possible, as previously noted, that in patients with xanthomatosis significant input occurred in body tissues by increased local synthesis. This would "shift the case" (2) and would mean that $\mathrm{M}$ has been underestimated. Be that as it may, the data suggest that the xanthoma cholesterol pool is relatively small in relation to the massive enlargement of the exchangeable body masses of cholesterol, and that unidentified factors, possibly genetic (13), may be determinant in xanthoma formation, rather than xanthoma formation being the passive consequence of an indefinite expansion of cholesterol pools. Finally, it must be kept in mind that the interpretation of these calculations depends on the validity of the model, and on the technical limitations and error of the methods available. Nevertheless, the inspection of the data in Table VI indicates strong correlation between the level of serum cholesterol and the size of body masses of cholesterol as measured by the present methods in patients with normal serum lipids and hypercholesterolemia.

\section{ACKNOWLEDGMENTS}

We thank Dr. Edward H. Ahrens, Jr., Dr. Edward Meilman, Dr. Joseph Shapiro, and Dr. Francis P. Chinard for their interest and advice. Gas-liquid chromatographic analysis of the xanthoma samples was kindly carried out by $\mathrm{Dr}$. Erwin H. Mosbach and Mr. Ihor Bekersky, and the dibromination procedure by Dr. Morton Urivetzky. Dr. Frederick $T$. Zugibe performed the autopsy. The technical assistance of Mrs. Tea. E. Siil, Mrs. Lois R. Markowski, and Mrs. Estelle F. Fisher is gratefully acknowledged.

This work was supported in part by grants from the Nassau Heart Association, The Alan Kahn Memorial Fund, and by Grants HE 12879 and HE 12974 from the U. S. Public Health Service.

\section{REFERENCES}

1. Goodman, D. S., and R. P. Noble. 1968. Turnover of plasma cholesterol in man. J. Clin. Invest. 47: 231.

2. Samuel, P., C. M. Holtzman, E. Meilman, and W. Perl. 1968. Effect of neomycin on exchangeable pools of cholesterol in the steady state. J. Clin. Invest. 47: 1806.

3. Grundy, S. M., and E. H. Ahrens, Jr. 1968. Measurements of cholesterol turnover, synthesis and absorption in man, carried out by isotope kinetic and sterol balance methods. J. Lipid Res. 10: 91.

4. Nestel, P. J., H. M. Whyte, and DeW. S. Goodman. 1969. Distribution and turnover of cholesterol in humans. J. Clin. Invest. 48 : 982.

5. Perl, W., and P. Samuel. 1969. Input-output analysis for total input rate and total traced mass of body cholesterol in man. Circ. Res. 25 : 191.

6. Samuel, P., and W. Perl. 1970. Long-term decay of serum cholesterol radioactivity: body cholesterol metabolism in normals and in patients with hyperlipoproteinemia and atherosclerosis. J. Clin. Invest. 49: 346.

7. Wilson, J. D. 1970. The measurement of the exchangeable pools of cholesterol in the baboon. J. Clin. Invest. 49: 655 .

8. Abell, L. L., B. B. Levy, B. B. Brodie, and F. E. Kendall. 1952. A simplified method for the estimation of total cholesterol in serum and demonstration of its specificity. J. Biol. Chem. 195: 357.

9. Van Handel, E., D. B. Zilversmit, and K. Bowman. 1957. Micromethod for the direct determination of serum triglycerides. J. Lab. Clin. Med. 50: 152.

10. Fredrickson, D. S., and R. S. Lees. 1966. Familial hyperlipoproteinemia. In The Metabolic Basis of Inherited Disease. J. B. Stanbury, J. B. Wyngaarden, and D. S. Fredrickson, editors. McGraw-Hill Book Company, New York. 429.

11. Quimby, E. H., and S. Feitelberg. 1963. Radioactive Isotopes in Medicine and Biology. Lea \& Febiger, Philadelphia. 199.

12. Fieser, L. F. 1955. Cholesterol, $\Delta^{5}$-cholesten-3-one, and $\Delta^{4}$-cholesten-3-one. Org. Syn. 35: 43.

13. Meilman, E., C. M. Holtzman, and P. Samuel. 1964. Familial hypercholesterolemia and xanthomatosis. Report on a rare type of kindred. Amer. J. Med. 36: 227.

14. Samuel, P., C. M. Holtzman, E. Meilman, and I. Sekowski. 1970. Reduction of serum cholesterol and triglyceride levels by the combined administration of neomycin and clofibrate. Circulation. 41: 109.

15. Zilversmit, D. B., C. Entenman, and M. C. Fishler. 1943. On the calculation of turnover time and turnover rate from experiments involving the use of labeling agents. J. Gen. Physiol. 26: 325.

16. Sheppard, C. W. 1962. Basic Principles of the Tracer Method. John Wiley \& Sons Inc., New York. 79.

17. Bergner, P. E. E. 1964. Tracer dynamics and the determination of pool sizes and turnover factors in metabolic systems. J. Theor. Biol. 6: 137.

18. Perl, W., R. M. Effros, and F. P. Chinard. 1969. Indicator equivalence theorem for input rates and regional masses in multi-inlet steady state systems with partially labeled input. J. Theor. Biol. 25: 297.

19. Perl, W. 1971. Stimulus-response method for flows and volumes in slightly perturbed constant parameter systems. Bull. Math. Biophys. $33: 225$.

20. Wilson, J. D. 1963. Studies on the origin of the lipid components of xanthomata. Circ. Res. 12: 472.

21. Moutafis, C. D., and N. B. Myant. 1969. The metabolism of cholesterol in two hypercholesterolemic patients treated with cholestyramine. Clin. Sci. 37: 443.

Body Cholesterol Kinetics in Man 
22. Quintão, E., S. M. Grundy, and E. H. Ahrens, Jr. 1971. An evaluation of four methods for measuring cholesterol absorption by the intestine in man. J. Lipid Res. 12: 221.

23. Khan, B., G. E. Cox, and K. Asdel. 1963. Cholesterol in human tissues. Arch. Pathol. 76: 369.

24. Field, H. Jr., L. S. Swell, P. E. Schools, Jr., and C. R. Treadwell. 1960. Dynamic aspects of cholesterol metabolism in different areas of the aorta and other tissues in man and their relationship to atherosclerosis. Circulation. $22: 547$.
25. Chobanian, A. V., and W. Hollander. 1962. Body cholesterol metabolism in man. I. The equilibration of serum and tissue cholesterol. J. Clin. Invest. 41: 1732.

26. Avigan, J., D. Steinberg, and M. Berman. 1962. Distribution of labeled cholesterol in animal tissues. $J$. Lipid Res. 3 : 216.

27. Spritz, N., E. H. Ahrens, Jr., and S. M. Grundy. 1965. Sterol balance in man as plasma cholesterol concentrations are altered by exchanges of dietary fats. $J$. Clin. Invest. $44: 1482$. 